Research Article

\title{
The Effect of Tempe Dietary Intake on Plasma Glucose Level in Elderly Patients with Type 2 Diabetes Mellitus
}

\author{
Grace Puspasari*, Drupadi Dillon**, Budiman*** \\ * Biochemistry Department Faculty of Medicine Maranatha Christian University \\ ** Faculty of Medicine Maranatha Christian University \\ Jl. Prof. Drg. Suria Sumantri MPH No. 65 Bandung 40164 Indonesia \\ Email:g.puspasari@yahoo.com
}

\begin{abstract}
The aim of the study was to investigate the effect of daily intake of 100 grams tempe for four weeks on plasma glucose level in elderly patients with type 2 diabetes mellitus. This study was a parallel randomized clinical trial. Subjects were 30 diabetic elderly living in four nursing homes in Jakarta. In the study subjects were assigned to two groups using block randomization. All subjects had to take diabetic regiment with calorie and macronutrient following diabetic recommendation diet. The treatment group $(n=16)$ received tempe, while control group $(n=14)$ received legumes other than tempe. Fasting plasma glucose level (FPG) was assessed before and after intervention. Unpaired $t$ test and Mann Whitney were used to analyzed data with the 5\% significance level. There were 27 subjects completed the study: 15 of treatment group and 12 of control group. Both group were comparable in age, gender, BMI, calorie and macronutrient intake before treatment. Fat, fiber, and isoflavone intake were significantly higher in treatment group compare to control group. Decrease in FPG after intervention were observed but were statisticaly insignificant. In conclusion daily intake of 100 grams tempe for four weeks did not decrease FPG.
\end{abstract}

Keywords: elderly, plasma glucose level, tempe, type 2 diabetes 
Journal of Medicine and Health

The Effect of Tempe

Vol.1 No.6 August 2017

Research Article 


\title{
Pengaruh Pemberian Tempe terhadap Kadar Glukosa Darah Penderita Diabetes Melitus Tipe 2 Usia Lanjut
}

\author{
Grace Puspasari*, Drupadi Dillon*, Budiman** \\ *Bagian Biokimia Fakultas Kedokteran Universitas Kristen Maranatha \\ ** Fakultas Kedokteran Universitas Kristen Maranatha \\ Jl. Prof. Drg. Suria Sumantri MPH No. 65 Bandung 40164 Indonesia \\ Email: g.puspasari@yahoo.com_
}

\begin{abstract}
Abstrak
Tujuan penelitian ini adalah untuk mengetahui pengaruh pemberian 100 gram tempe per hari selama empat minggu terhadap kadar glukosa darah pada penderita diabetes mellitus tipe 2 (DM tipe 2) usia lanjut (usila). Metode penelitian uji klinis pararel, acak, terbuka pada 30 orang penderita DM tipe 2 usila di panti wredha di Jakarta. Subjek dibagi menjadi dua kelompok dengan randomisasi blok. Seluruh subjek diberikan pengaturan diet DM sesuai PERKENI. Kelompok perlakuan sebanyak 16 orang diberikan 100 gram tempe, sedangkan kelompok kontrol sebanyak 14 orang diberikan kacang-kacangan sebagai pengganti tempe dengan takaran kalori yang setara. Pemeriksaan kadar glukosa darah puasa (GDP) dilakukan pada awal dan akhir perlakuan. Analisis data menggunakan uji t tidak berpasangan dan uji Mann Whitney dengan batas kemaknaan 5\%. Subjek yang mengikuti penelitian secara lengkap sebanyak 27 orang yang terdiri dari 15 orang kelompok perlakuan dan 12 kelompok kontrol. Pada awal penelitian baik usia, jenis kelamin, IMT, asupan kalori dan zat gizi makro dari kedua kelompok perlakuan tidak berbeda bermakna. ( $>0,05)$. Asupan lemak, serat dan isoflavon pada kelompok perlakuan lebih tinggi dibandingkan kelompok kontrol. Setelah perlakuan terlihat penurunan kadar GDP yang tidak berbeda bermakna antara kedua kelompok perlakuan. Pemberian 100 gram tempe selama 4 minggu tidak menurunkan kadar GDP.
\end{abstract}

Kata kunci: DM tipe 2, glukosa darah, usia lanjut, tempe 


\section{Pendahuluan}

Diabetes melitus merupakan salah satu masalah kesehatan yang sering terjadi pada usia lanjut (usila). Pada tahun 2030 diperkirakan penderita DM tipe 2 usila mencapai lebih dari 84 juta orang di Negara berkembang. ${ }^{1}$ Beberapa perubahan fisiologis pada usila antara lain menurunnya sekresi insulin dan resistensi insulin diduga menjadi penyebab DM tipe 2 pada usila. Perubahan gaya hidup pada usila, yaitu ketidakseimbangan antara aktivitas fisik dengan asupan kalori juga berperan dalam terjadinya DM tipe 2 pada usila. ${ }^{2}$

Beberapa penelitian menunjukkan bahwa kedelai dapat menurunkan kadar glukosa darah. Efek penurunan glukosa darah tersebut lebih baik pada pemberian kedelai dalam bentuk utuh dibandingkan komponen protein atau isoflavon kedelai saja. ${ }^{3,4}$ Penelitian dengan memberikan 69 gram kedelai selama empat minggu mendapatkan hasil penurunan kadar GDP dan GDPP yang lebih baik pada kelompok perlakuan dengan kelompok kontrol. ${ }^{5}$ Tempe merupakan hasil fermentasi kedelai yang mempunyai komponen kedelai utuh, jumlah kedelai untuk menghasilkan 50 gram tempe adalah kurang lebih 30 gram kedelai, sehingga dengan 69 gram kedelai dapat menghasilkan 100 gram tempe. ${ }^{6}$ Tujuan penelitian ini adalah untuk mengetahui pengaruh asupan tempe terhadap kadar glukosa darah penderita DM tipe 2 usila, yang meliputi kadar glukosa darah puasa (GDP).

\section{Metode}

Penelitian ini merupakan uji klinis pararel terbuka dengan alokasi acak yang membandingkan kelompok perlakuan yang mendapat 100 gram tempe dalam diet DM setiap hari selama 4 minggu berturut-turut, dengan kelompok K yang hanya mendapat diet DM saja. Seleksi subyek penelitian dilakukan pada 112 orang populasi terjangkau di empat panti wredha di Jakarta, yaitu Panti Wredha Wisma Mulia, Panti Wredha Budi Mulia Jelambar, Panti Wredha Budi Mulia Cengkareng, dan Panti Wredha Santa Anna. Penelitian dilakukan dari bulan April hingga bulan Juni 2010. Penelitian ini telah mendapatkan persetujuan Komisi Etik Penelitian dengan nomor 99/PT02.FK/ETIK/2010.

Kriteria inklusi adalah kadar GDP vena $\geq 126 \mathrm{mg} / \mathrm{dL}$, dan bersedia mengikuti penelitian, sedangkan kriteria eksklusi adalah telah mendapat terapi insulin, menerima perubahan dosis obat hipoglikemik oral $(\mathrm{OHO})$ satu minggu sebelum penelitian, menderita gangguan fungsi hati (SGOT >102 $\mathrm{u} / \mathrm{L}$, SGPT >147 U/L), menderita gangguan fungsi ginjal (kreatinin plasma $>1,2 \mathrm{mg} / \mathrm{dL}$ ). Kriteria pengeluaran adalah apabila selama periode penelitian subyek hanya mengkonsumsi tempe $<80 \%$ dari jumlah yang ditetapkan mendapat terapi insulin atau menerima perubahan dosis OHO, atau memerlukan perawatan di rumah sakit, dan apabila subyek menolak melanjutkan penelitian. Berdasarkan kriteria 
inklusi dan eksklusi didapatkan 30 orang subyek, kemudian dilakukan pengacakan dengan randomisasi blok dan didapatkan kelompok perlakuan sebanyak 16 orang dan kelompok kontrol 14 orang. Sebanyak tiga orang subyek tidak bersedia dilakukan pengambilan darah, Hasil akhir analisis menyertakan 27 orang subyek yang terdiri dari 15 orang kelompok perlakuan dan 12 orang kelompok kontrol.

Selama penelitian dilakukan pencatatan asupan dengan metode food record 3x 24 jam, data yang dianalisis pada food record adalah asupan kalori, makronutrien dan isoflavon. Pengukuran berat badan (BB) dan tinggi badan (TB) berdasarkan tinggi lutut dilakukan untuk menghitung indeks massa tubuh (IMT). Pemeriksaan kadar GDP dilakukan sebelum dan sesudah perlakuan. Periode run in dilakukan selama 1 minggu yaitu dengan memberikan diet DM sesuai kebutuhan kalori individu menurut persamaan Harris-Bennedict, ditambah faktor stress $10 \%$ dan faktor aktivitas fisik $10 \%$ dari kebutuhan kalori basal $(\mathrm{KKB})^{7}$ dengan komposisi makronutrien $15 \%$ kalori dari protein, $20 \%$ kalori dari lemak dan $65 \%$ kalori dari hidrat arang. ${ }^{8}$ Asupan tempe dan kedelai tidak diperbolehkan selama periode ini. Pada periode perlakuan seluruh subyek penelitian diberikan diet DM, pada kelompok perlakuan sebanyak 10 gram asupan protein nabati diberikan dalam bentuk 100 gram tempe, sedangkan kelompok perlakuan mendapatkan 10 gram asupan protein nabati dalam bentuk kacang-kacangan selain tempe. Tempe yang diberikan adalah tempe yang didapatkan dari produsen tempe khusus yang dijual di pasar di Jakarta Barat. Tempe yang diberikan mempunyai kandungan isoflavon sebesar $41 \mathrm{mg} / 100$ gram.

Data dianalisis secara statistik dengan program SPSS versi 11.5 dengan batas kemaknaan $p<0,05$. Normalitas data diuji dengan uji Saphiro-Wilk, untuk membandingkan data kelompok perlakuan dengan kelompok kontrol dilakukan dengan uji T tidak berpasangan atau uji Mann-Whitney. Data berdistribusi normal diuji dengan uji $\mathrm{T}$ tidak berpasangan, sedangkan data yang tidak berdistribusi normal diuji dengan uji Mann-Whitney.

\section{Hasil}

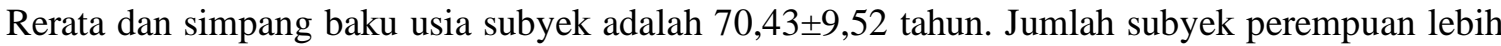
banyak dibandingkan laki-laki, yaitu sebesar $63,5 \%$. Sebanyak $46,7 \%$ subyek mempunyai status gizi yang normal. Sebanyak $80 \%$ subyek belum mendapatkan terapi OHO dan baru terdeteksi DM tipe 2 saat penelitian. Sebanyak 20\% subyek telah mendapat pengobatan OHO selama 1 tahun yaitu 10\% menerima sulfonylurea dan $10 \%$ menerima metformin. 
Tabel 1 Asupan Kalori, Karbohidrat, Lemak dan Protein Kelompok Perlakuan dan Kontrol Selama Perlakuan

\begin{tabular}{|c|c|c|c|}
\hline Variabel & $\begin{array}{c}\text { Kelompok Perlakuan } \\
(n=16)\end{array}$ & $\begin{array}{c}\text { Kelompok Kontrol } \\
(n=14)\end{array}$ & $\mathbf{p}$ \\
\hline \multicolumn{4}{|l|}{ Asupan kalori ${ }^{\mathrm{b}} \%$} \\
\hline Minggu I & $88,38 \pm 15,19$ & $77,70 \pm 15,70$ & $0,069^{t}$ \\
\hline Minggu II & $98,83 \pm 11,23$ & $85,99 \pm 2,28$ & $0,007^{\mathrm{t} \#}$ \\
\hline Minggu III & $98,01 \pm 13,59$ & $81,98 \pm 11,32$ & $0,002^{\mathrm{t} \#}$ \\
\hline Minggu IV & $93,13(68,57-126,96)$ & $79,19(64,50-145,42)$ & $0,005^{\mathrm{m} \#}$ \\
\hline \multicolumn{4}{|l|}{ Asupan karbohidrat ${ }^{\mathrm{b}} \%$} \\
\hline Minggu I & $53,81 \pm 5,28$ & $58,97 \pm 6,77$ & $0,027^{\mathrm{t} \#}$ \\
\hline Minggu II & $50,53 \pm 5,99$ & $51,72 \pm 7,60$ & $0,637^{t}$ \\
\hline Minggu III & $53,55 \pm 7,38$ & $57,99 \pm 6,18$ & $0,087^{t}$ \\
\hline Minggu IV & $54,36(37,53-63,96)$ & $53,23(50,65-69,88)$ & $0,074^{\mathrm{m}}$ \\
\hline \multicolumn{4}{|l|}{ Asupan lemak ${ }^{\mathrm{b}} \%$} \\
\hline Minggu I & $31,53 \pm 4,80$ & $27,75 \pm 4,90$ & $0,042^{\mathrm{t} \#}$ \\
\hline Minggu II & $32,08(27,35-48,53)$ & $30,24(25,67-47,61)$ & $0,360^{\mathrm{m}}$ \\
\hline Minggu III & $27,82(23,15-46,23)$ & $24,53(21,25-37,48)$ & $0,031^{\mathrm{m} \#}$ \\
\hline Minggu IV & $31,92 \pm 5,86$ & $27,94 \pm 4,88$ & $0,052^{\mathrm{t} \#}$ \\
\hline \multicolumn{4}{|l|}{ Asupan protein ${ }^{\mathrm{b}} \%$} \\
\hline Minggu I & $16,18 \pm 1,21$ & $14,03 \pm 2,59$ & $0,011^{\mathrm{t} \#}$ \\
\hline Minggu II & $16,68 \pm 2,43$ & $16,16 \pm 2,85$ & $0,598^{t}$ \\
\hline Minggu III & $16,81(12,24-20,53)$ & $17,24(11,59-19,73)$ & $0,561^{\mathrm{t}}$ \\
\hline Minggu IV & $14,46(12,41-19,68)$ & $14,18(9,38-19,29)$ & $0,480^{\mathrm{m}}$ \\
\hline \multicolumn{4}{|l|}{ Asupan serat ${ }^{c}$} \\
\hline Minggu I & $10,24(8,88-13,87)$ & $9,45(6,9-12,76)$ & $0,011^{\mathrm{m} \#}$ \\
\hline Minggu II & $11,55 \pm 1,16$ & $8,11 \pm 1,51$ & $<0,001^{\mathrm{t} \#}$ \\
\hline Minggu III & $12,12 \pm 1,53$ & $9,47 \pm 2,45$ & $<0,001^{\mathrm{t} \#}$ \\
\hline Minggu IV & $11,39 \pm 2,29$ & $7,66 \pm 1,13$ & $<0,001^{\mathrm{t} \#}$ \\
\hline \multicolumn{4}{|l|}{ Asupan isoflavon ${ }^{\mathrm{d}}$} \\
\hline Minggu I & $43,25(35,87-47,99)$ & $3,17(0,92-12,04)$ & $<0,001^{\mathrm{m} \#}$ \\
\hline Minggu II & $48,14 \pm 3,94$ & $7,29 \pm 4,25$ & $<0,001^{\mathrm{t} \#}$ \\
\hline Minggu III & $46,39(39,96-47,42)$ & $4,79(1,19-9,57)$ & $<0,001^{\mathrm{m} \#}$ \\
\hline Minggu IV & $47,98 \pm 6,23$ & $5,44 \pm 4,32$ & $<0,001^{\mathrm{t} \#}$ \\
\hline $\begin{array}{l}\text { Keterangan: } \\
{ }^{*}=\text { rerata } \pm \text { simpang baku } \\
\mathrm{a}=\text { persentase terhadap keb } \\
{ }^{\mathrm{b}}=\text { persentase terhadap asu } \\
\mathrm{t}=\text { uji } \mathrm{t} \text { tidak berpasangan } \\
\text { Batas kemaknaan } \mathrm{p} \leq 0,05\end{array}$ & $\begin{array}{l}\text { n (minimum - maksimum) } \\
\text { ergi total } \\
\text { total }\end{array}$ & $\begin{array}{l}.000 \text { kkal } \\
\text { ann-Whitney } \\
\text { kna }\end{array}$ & \\
\hline
\end{tabular}

Asupan kalori pada kelompok kontrol lebih rendah dibandingkan kelompok perlakuan, namun tidak berbeda bermakna ( $>0,05)$. Selama penelitian asupan lemak tinggi sedangkan asupan serat rendah pada kedua kelompok subyek. Asupan lemak, serat dan isoflavon pada kelompok perlakuan lebih tinggi secara bermakna dibandingkan kelompok kontrol. 
Tabel 2 Perubahan Berat Badan dan Indeks Massa Tubuh Kelompok Perlakuan dan Kontrol Setelah Perlakuan

\begin{tabular}{|c|c|c|c|}
\hline Variabel & $\begin{array}{c}\text { Kelompok Perlakuan } \\
(n=15)\end{array}$ & $\begin{array}{c}\text { Kelompok Kontrol } \\
(n=12)\end{array}$ & $\mathbf{P}$ \\
\hline BB awal & $52,45(31,90-68,60)$ & $52,90(25,50-62,00)$ & $0,755^{\mathrm{m}}$ \\
\hline BB akhir & $50,65 \pm 10,66$ & $51,70 \pm 9,55$ & $0,781^{\mathrm{t}}$ \\
\hline Perubahan BB & $-0,27 \pm 1,62$ & $0,17 \pm 1,28$ & $0,408^{t}$ \\
\hline IMT awal & $22,69(15,26-27,67)$ & $21,70(11,46-25,08)$ & $0,480^{\mathrm{m}}$ \\
\hline IMT akhir & $21,17(15,76-27,91)$ & $21,84(11,28-24,78)$ & $0,561^{\mathrm{m}}$ \\
\hline $\begin{array}{l}\text { Keterangan: } \\
=\text { rerata } \pm \text { simpang baku } \\
\text { t=uji t tidak berpasangan } \\
\text { Batas kemaknaan } \mathrm{p} \leq 0,05\end{array}$ & $\begin{array}{l}{ }^{\mathrm{m}}=\mathrm{u} \\
{ }^{\#}=\mathrm{b}\end{array}$ & $\begin{array}{l}\text { nn-Whitney } \\
\text { na }\end{array}$ & \\
\hline
\end{tabular}

Setelah perlakuan kedua kelompok subyek tidak mengalami perubahan berat badan maupun IMT yang bermakna. Kadar GDP menurun namun tidak berbeda bermakna antara kelompok perlakuan dengan kontrol.

Tabel 3 Kadar Glukosa Darah Puasa Kelompok Perlakuan Dan Kontrol Setelah Perlakuan

\begin{tabular}{lccc}
\hline \begin{tabular}{c} 
Kadar Glukosa Darah \\
\multicolumn{1}{c}{$(\mathbf{m g} / \mathbf{d L})$}
\end{tabular} & $\begin{array}{c}\text { Kelompok Perlakuan } \\
(\mathbf{n = 1 5})\end{array}$ & $\begin{array}{c}\text { Kelompok Kontrol } \\
(\mathbf{n = 1 2})\end{array}$ & $\mathbf{P}$ \\
\hline Puasa awal & $132,44 \pm 44,13$ & $147,29 \pm 36,64$ & $0,344^{\mathrm{t}}$ \\
Puasa akhir & $127,27 \pm 45,83$ & $141,00 \pm 46,84$ & $0,451^{\mathrm{t}}$ \\
Perubahan Puasa & $-7,20 \pm 15,88$ & $-8,33 \pm 33,60$ & $0,909^{\mathrm{t}}$
\end{tabular}

Keterangan:

${ }^{\mathrm{t}}=\mathrm{uji} \mathrm{t}$ tidak berpasangan

Batas kemaknaan $\mathrm{p} \leq 0,05$

" $=$ bermakna

\section{Diskusi}

Perubahan kadar GDP tidak berbeda bermakna antara kelompok P dan K. Kadar GDP pada penelitian ini cenderung menurun, meskipun tidak bermakna secara statistik. Lama penelitian dapat menjadi faktor yang mempengaruhi hasil penelitian ini. Penelitian Fujita yang memberikan fermentasi kedelai dengan Aspergilus sp, yaitu Touchi sebanyak 0,3 gram tiga kali sehari selama tiga bulan, hasilnya didapatkan penurunan kadar GDP sejak bulan pertama, namun tidak berbeda bermakna secara statistik. Setelah bulan ke tiga, penurunan kadar GDP berbeda bermakna dibandingkan kelompok kontrol yang mendapat plasebo. Efek penurunan GDP tersebut diduga disebabkan salah satunya oleh efek hambatan enzim glukosidase- $\alpha$, misalnya acarbose dapat menurunkan kadar GDP dan memperbaiki kadar $\mathrm{HbA}_{1 \mathrm{c}}$. 
Touchi mempunyai efek menyerupai kerja acarbose yaitu dapat menghambat enzim glukosidase- $\alpha$ pada $\mathrm{IC}_{50} 1,1 \mathrm{~g} / \mathrm{L} .{ }^{9}$ Tempe juga mempunyai efek menghambat enzim glukosidase- $\alpha$ pada $\mathrm{IC}_{50} 1,4 \mathrm{mg} / \mathrm{mL},{ }^{10}$ meski demikian pada penelitian ini penurunan kadar GDP pada kelompok perlakuan tidak berbeda bermakna dibandingkan kelompok kontrol. Penelitian ini dilakukan selama 1 bulan. Waktu yang lebih lama mungkin dibutuhkan untuk mendapatkan hasil penurunan kadar GDP yang bermakna.

Berbagai komponen dalam kedelai antara lain protein, serat, asam lemak tak jenuh dan isoflavon bekerja sinergis dalam menurunkan kadar glukosa darah. Pada studi Azadbakht, dkk mendapatkan bahwa penurunan GDP paling besar pada kelompok yang mendapat $30 \mathrm{mg}$ kacang kedelai dibandingkan dengan kelompok yang mendapat 30 gram protein kedelai, maupun kelompok kontrol. Kandungan zat gizi tempe yang diberikan dalam penelitian ini sebanding dengan zat gizi kacang kedelai dalam penelitian Azadbakht, meski demikian kandungan isoflavon pada tempe lebih rendah. Kacang kedelai yang digunakan dalam penelitian Azadbakht mengandung $102 \mathrm{mg}$ isoflavon, ${ }^{4}$ sedangkan pada penelitian ini tempe mengandung $41 \mathrm{mg}$ isoflavon. Demikian pula kandungan serat pada tempe yang digunakan pada penelitian ini lebih kecil yaitu 6,1 gram dalam 100 gram tempe, dibandingkan penelitian Chang sebesar 18 gram dalam 69 gram kedelai. ${ }^{5}$ Pemberian tempe dengan kandungan isoflavon dan serat yang lebih rendah pada penelitian ini belum memberikan efek penurunan glukosa darah, atau membutuhkan waktu yang lebih lama untuk terjadinya efek tersebut.

Penelitian tentang kedelai pada umumnya tidak menyertakan pencatatan asupan, atau hanya melakukan pencatatan asupan pada awal dan akhir penelitian, sehingga terdapat kemungkinan bahwa perbaikan kadar glukosa darah pada penelitian tersebut disebabkan oleh faktor kepatuhan subyek akan regimen diet lebih baik. Pada penelitian ini pencatatan asupan dilakukan sejak sebelum perlakuan hingga periode perlakuan berakhir, sehingga lebih menggambarkan asupan subyek yang sebenarnya. Data menunjukkan bahwa kedua kelompok subyek mengkonsumsi lemak yang tinggi dan serat yang rendah, dimana asupan lemak pada kelompok perlakuan lebih tinggi secara bermakna dibanding kelompok kontrol. Hal tersebut dapat menyebabkan tidak terjadinya penurunan kadar glukosa darah yang bermakna.

Kadar GDP dapat dipengaruhi oleh lama dan progresivitas penyakit DM. Sebagian besar subyek (80\%) baru terdeteksi DM pada saat penapisan, sehingga tidak diketahui lamanya subyek menderita DM. Sebanyak 6 orang subyek telah mendapat terapi OHO yang terbagi di kelompok perlakuan dan kontrol, namun perubahan kadar GDP antara subyek yang mendapat OHO dan belum mendapat OHO di kedua kelompok perlakuan tidak berbeda bermakna. Hal ini menunjukkan bahwa pada penelitian ini pemakaian 
obat DM minimal pengaruhnya pada perubahan kadar glukosa darah, yang mengindikasikan bahwa tidak terlihatnya perbaikan kadar glukosa darah lebih dipengaruhi oleh perlakuan yang diberikan.

Penelitian ini menggunakan desain paralel dengan randomisasi yang berhasil membagi dua kelompok yang homogen, namun desain crossover lebih ideal untuk mengeliminasi variasi antar individu karena subyek menjadi pembanding untuk dirinya sendiri.

\section{Simpulan}

Pada studi pararel ini pemberian 100 gram tempe setiap hari berturut-turut selama empat minggu sebagai salah satu sumber protein nabati dalam diet DM pada penderita DM tipe 2 usila tidak menurunkan kadar GDP dibandingkan pemberian diet DM saja. Pada penelitian ini terdapat beberapa keterbatasan dalam pelaksanaan dalam penelitian sehingga efek tempe terhadap glukosa darah belum terlihat. Pemberian tempe sebagai salah satu komponen dalam terapi nutrisi DM masih dapat dipertimbangkan, karena tempe merupakan salah satu makanan asal kedelai yang telah dianjurkan sebagai salah satu komponen terapi nutrisi pada DM.

\section{Daftar Pustaka}

1. Djokomoeljanto R. Endokrinologi pada usia lanjut. Dalam: Martono HH, Pranarka K, editor. Buku ajar Boedhi-Darmojo Geriatri (Ilmu Kesehatan Usia Lanjut). Edisi ke 4. Jakarta: Balai Penerbit Fakultas Kedokteran Universitas Indonesia, 2009; hal 401-05.

2. Kirkman MS, Briscoe VJ, Clark N, Florez H, Haas LB, Halter JB, et al. Diabetes in Older Adults. Diabetes Care 2012;35(12):2650-64.

3. Gonzales S, Jayagopal V, Kilpatrick ES, Chapman T, Atkins SL. Effects of isoflavone dietary supplementation on cardiovascular risk factors in type 2 diabetes. Diabetes Care 2007;30:1871-73.

4. Azadbakht L, Kimiagar M, Mehrabi Y, Esmaillzadeh A, Padyab M. Soy inclusion in the diet improves features of the metabolic syndrome: a randomized crossover study in postmenopausal women. Am J Clin Nutr 2007;85:735-41.

5. Chang JH, Kim MS, Kim TW, Lee SS. Effect of soybean supplementation on blodd glucose, plasma lipid levels and erythrocyte antioxidant enzyme activity in type 2 diabetes mellitus patients. Nutr Res Prac 2008;2(3):152-57.

6. Nout MJR, Kiers JL. Tempe fermentation, innovation and functionality: update into the third millennium. Journal of Applied Microbiology 2005;98:789-95.

7. Heimburger DC. Ard JD. Handbook of Clinical Nutrition. 4th ed. Mosby Inc, Philadelphia, 2006. P262-64.

8. PB PERKENI. Konsensus pengeleolaan dan pencegahan diabetes melitus tipe 2 di Indonesia. Cetakan pertama. Jakarta: PB PERKENI, 2015. Hal 20-26.

9. Fujita H, Yamagami T, Oshima K. Long term ingestion of a fermented soybean-derived touchi extract with $\alpha$-glucosidase inhibitory activity is safe and effective in human with borderline and mild type 2 diabetes. J Nutr 2001;131:2105-08.

10. Suarsana IN, Priosoeryanto BP, Bintang M, Wresdiati T. Aktivitas daya hambat enzim $\alpha$-glukosidase dan efek hipoglikemik ekstrak tempe pada tikus diabetes. Journal veteriner 2008;9(3):122-27. 